УДК 636.4.082

(C) 2012

Бирта Г. А., доктор сельскохозяйственных наук,

Бургу Ю. Г., кандидат сельскохозяйственных наук

Высшее учебное заведение Укоопсоюза «Полтавский университет экономики и торговли»

\title{
ВЛИЯНИЕ ГЕНОТИПА НА МЯСНЫЕ КАЧЕСТВА СВИНЕЙ
}

\section{Рецензент - доктор сельскохозяйственных наук В. П. Рибалко}

\begin{abstract}
Генетичні дослідження дозволили встановити ступінь спадковості господарсько корисних ознак, а також їх взаємозв'язок за певних умов годівлі й утримання свиней. Знання циих показників і використання їх у селекиійно-племінній роботі дає змогу удосконалювати породи в бажаному напрямі продуктивності. Розділити ознаки, залежні лише від внутрішніх чинників або тільки від зовнішніх умов, практично неможливо. Проте можна визначити ступінь впливу тих й інших на формування конкретних властивостей тварин у проиесі їх розвитку. Це особливо важливо по відноченню до ознак, щзо обумовлюють продуктивні якості тварин. Дані

проведених досліджень підтверджують, щуо в однакових умовах годівлі й утримання полтавські м'ясні, великі білі та миргородські свині при однаковій живій масі мали різні забійні і м'ясні якості.
\end{abstract}

Ключевые слова: мясо, сало, порода, корейка, грудинка, убойный выход, убойная масса, выход мяса, выход сала, живая масса.

Постановка проблемы. Изменчивость признаков, обусловленная наследственностью организма, называется наследственностью. Наследственность - это способность признака претерпевать генотипические изменения внутри популяции животных. Удельный вес генотипической и паратипической (обусловлена влиянием внешней среды) изменчивости в общей фенотипической изменчивости в разных случаях различен, следовательно, и степень наследуемости признаков неодинаковая. Величина наследуемости признака зависит от трех основных факторов: специфики изучаемого признака, генетической структуры стада и условий внешней среды.

Развитие и формирование определенных признаков происходит в зависимости от условий жизни особи, но в пределах нормы реакции ее генотипа. Хозяйственно полезные признаки определяются многими генами, а также условиями, в которых протекает развитие этих признаков.

Анализ основных исследований и публикаций по данной проблеме. Интенсивная селекция свиней на мясность в ряде зарубежных стран была начата несколько раньше, чем в нашей стране, в результате чего уже созданы новые мя- сные породы или значительно усовершенствованы по мясности существующие генотипы. Так, например, в Дании, Швеции, Великобритании, Нидерландах и США - 85-95 \% свиней в настоящие время - животные мясного направления продуктивности [2-3].

Как свидетельствует мировая практика, интенсивная селекция свиней на увеличение мясности при безвыгульном содержании привели к ухудшению качества свинины, что выражается в резком увеличении случаев появления палевой, мягкой, экссудативной свинины, не имеющей товарной ценности. Другим отклонением в качестве свиного мяса (возникающим на той же основе) являются туши с темной, плотной и сухой мышечной тканью. Как палевая, так и темная свинина малопригодны для приготовления колбас, консервирования и длительного хранения [1-3].

В связи с возрастающим спросом населения на нежирную свинину важное значение в нынешнее время приобретают не только количественные показатели, но и качество конечной продукции - мяса и сала.

Методика исследований. На опыт было поставлено 90 подсвинков: по 30 голов крупной белой, миргородской и полтавской мясной пород. Животные находились в одинаковых условиях кормления, ухода и содержания. Кормили свиней всех подопытных групп согласно норм по принципу: равное количество корма (по питательности и составу) на единицу живой массы.

Откорм свиней заканчивали по мере достижения животными живой массы 100 кг, производили контрольный убой, учитывая убойную массу, убойный выход, разрубку и обвалку туш по сортовым отрубам, химический анализ на содержание в них влаги, жира, белка и золы.

Результаты исследований. Результаты исследований показали, что убойная масса, убойный выход сравниваемых пород был достаточно высоким - 81,8-83,7 \% (табл. 1).

У свиней крупной белой породы за счет более тяжелой головы, ног, шкуры убойная масса и выход был выше, чем у других пород. Свиньи миргородской породы имели меньшую убойную 
СІЛЬСЬКЕ ГОСПОДАРСТВО. ТВАРИННИЦТВО

\begin{tabular}{|c|c|c|c|c|c|c|c|c|}
\hline \multicolumn{9}{|c|}{ 1. Убойные качества свиней } \\
\hline \multirow[b]{2}{*}{ Порода } & \multirow{2}{*}{$\begin{array}{c}\text { Живая } \\
\text { масса } \\
\text { перед } \\
\text { убоем, кг }\end{array}$} & \multicolumn{5}{|c|}{ Масса продуктов убоя, кг } & \multirow[b]{2}{*}{$\begin{array}{c}\text { Убойная } \\
\text { масса, } \\
\text { кг }\end{array}$} & \multirow[b]{2}{*}{$\begin{array}{c}\text { Убойный } \\
\text { выход, } \\
\text { \% }\end{array}$} \\
\hline & & $\begin{array}{c}\text { парной } \\
\text { туши }\end{array}$ & головы & ног & $\begin{array}{c}\text { внут- } \\
\text { реннего } \\
\text { сала }\end{array}$ & шкуры & & \\
\hline Полтавская мясная & 93,1 & 62,6 & 4,22 & 1,42 & 2,94 & 5,55 & 76,73 & 82,4 \\
\hline Крупная белая & 94,2 & 62,3 & 4,83 & 1,72 & 3,35 & 6,72 & 78,92 & 83,7 \\
\hline Миргородская & 93,7 & 60,7 & 4,41 & 1,58 & 3,88 & 6,10 & 76,67 & 81,8 \\
\hline
\end{tabular}

\section{2. Сортовая разрубка туш подопытных свиней}

\begin{tabular}{|c|c|c|c|c|c|c|c|c|}
\hline \multirow{2}{*}{ Порода } & \multirow{2}{*}{\begin{tabular}{c} 
Масса \\
охлаж- \\
\cline { 3 - 9 }
\end{tabular}} & \multicolumn{6}{|c|}{ денной } \\
\cline { 3 - 9 } & туши, кг & $\begin{array}{c}\text { лопа- } \\
\text { точная } \\
\text { часть }\end{array}$ & корейка & $\begin{array}{c}\text { грудин- } \\
\text { ка }\end{array}$ & $\begin{array}{c}\text { пояс- } \\
\text { ничная } \\
\text { часть }\end{array}$ & окорок & рулька & голяшка \\
\hline Полтавская мясная & 62,0 & 30,9 & 11,9 & 11,9 & 12,7 & 27,9 & 2,2 & 2,5 \\
\hline Крупная белая & 62,5 & 31,8 & 10,2 & 11,4 & 12,9 & 29,2 & 2,0 & 2,5 \\
\hline Миргородская & 61,0 & 31,1 & 12,1 & 11,3 & 13,8 & 27,2 & 2,1 & 2,4 \\
\hline
\end{tabular}

массу по сравнению с другими породами, но молодняк этой породы дал на 31,9 \% больший выход внутреннего сала, чем полтавской мясной, и на $15,8 \%$ больше, чем крупной белой.

Качество мяса, его пищевая ценность зависят от многих факторов, среди которых следует выделить такие как порода животных и анатомическое происхождение мяса. Известно, что при жизни животного разные части его тела несут различную механическую нагрузку. Поэтому в одной и той же туше в разных ее частях количественное соотношение тканей неодинаково. В связи с этим показатели сортовой классификации туш свиней изучаемых пород представляют большой интерес как для мясоперерабатывающих предприятий и потребителя свинины, так и для зоотехников-селекционеров (табл. 2).

Свиньи крупной белой породы отличались от других пород большим выходом передней части и задней - окорока. По выходу средней части корейки, грудинки и поясничной первое место занимали туши свиней миргородской породы, второе - полтавской мясной и последнее - крупной белой.

По выходу мясопродуктов II сорта (рульки и голяшки) в тушах свиней сравниваемых пород существенной разницы не отмечено (4,5-4,7\%).

Более легкая лопатка, а также хорошо развитая средняя часть и окорок свидетельствуют о беконных качествах свиней полтавской мясной породы.

Показатели выхода лопаточной части и окорока указывают на пригодность свиней крупной белой породы для производства ветчины.
Ценность отдельных отрубов свинины определяется содержанием в них более или менее ценных в пищевом отношении составных частей.

В тушах животных миргородской породы было на $6,9 \%$ больше шпига, чем у полтавской мясной, и на 5,7 \% больше, чем у крупных белых свиней. Последние имели несколько больший выход шкуры и костей.

Свиньи полтавской мясной породы по выходу мяса превосходили крупных белых на 2,4 \% и миргородских - на $6,4 \%$.

Сортовая обвалка показала, что передняя часть туши превосходила другие отруби I сорта по выходу мяса и костей. Большее количество костей $(12,9 \%)$ имели свиньи крупной белой породы, за ними (12,6\%) полтавской мясной и миргородской $(11,2 \%)$.

По выходу мяса первое место занимали свиньи полтавской мясной породы $(61,1 \%)$, второе - крупной белой $(58,8 \%)$, последнее - миргородской $(54,7 \%)$, которые дали наибольшее количество шпига.

Отношение мяса к шпигу в средней части, корейке, грудинке, пояснице полтавской мясной и крупной белой пород составляло $1: 1$, а у миргородской на 1 часть мяса приходилось 1,3 части шпига.

В окороке свиней полтавской мясной породы на 1 часть шпига приходилось 2,2 части мяса; крупной белой, соответственно, 1:2 и миргородской $-1: 1,4$.

Отруба II сорта всех трех пород характеризовались большим виходом костей и шкуры, составляющих 40-49 \% всей массы отруба. 
Очень ценной в пищевом отношении составной частью туш свиней является шпиг.

Свиньи миргородской породы по физикохимическим показателям шпига несколько отличались от других: у них было больше жира, выше температура плавления и застывания, меньше влаги и ниже йодное число.

Второе место по количеству жира в шпиге занимали свиньи крупной белой породы, но у них было несколько выше йодное число и ниже температура плавления. Шпиг свиней полтавской мясной породы содержал сравнительно больше воды.

\section{БИБЛИОГРАФИЯ}

1. Баньковський И. Б. Селекия на мясность и качество свинины // Тезисы докл. на 4-ой Международной конф. по проблеме «Научнопроизводственные аспекты развития отрасли свиноводства». - 1997. - С. 60.
Выводы: 1. В одинаковых условиях кормления и содержания свиньи полтавской мясной, крупной белой и миргородские свиньи при одинаковой живой массе имели различные убойные и мясные качества.

2. Сортовая обвалка показала, что передняя часть туши превосходила другие отруби I сорта по выходу мяса. Первое место занимали свиньи полтавской мясной породы, второе - крупной белой, последнее - миргородской, которые дали наибольшее количество шпига.

2. Бола С. / Цит. по Бугаев Н. И. : Оценка мясных качеств свиней. - М.: ВО Агропромиздат. 1988. -72 c.

3. Довідник 3 виробництва свинини / За ред. В. П. Рибалка / Х.: Еспада, 2001. - 336 с. 